\title{
Communication of nonearnings information at the financial statements release date*
}

\author{
Bong H. Han and Ross Jennings \\ University of Texas, Austin, TX 78712-1172, USA \\ James Noel \\ Unitersity of Michigan, Ann Arbor, MI 48109-1234, USA
}

Received December 1990, final version received August 1991

\begin{abstract}
This study examines whether annual financial statements filed with the Securities and Exchange Commission are timely sources of information for investors. We examine a summary measure, the probability of bankruptcy, through which the release of financial statements might communicate information to investors. The results indicate that a significant association exists between revisions in the probability of bankruptcy due to nonearnings data and security returns over the fiscal year, but that investors have largely revised their estimates of the probability of bankruptcy prior to the release of the full financial statements.
\end{abstract}

\section{Introduction}

An important role of accounting is to communicate financial or economic data about firms to decision makers. For an accounting disclosure to be of direct value to decision makers, it must revise their expectations of future outcomes. Such 'communication value' can occur when firms make preliminary earnings announcements and subsequently when firms release their financial statements to the public. Prior research [e.g., Beaver (1968), Morse (1981), and Patell and Wolfson (1984)] indicates that earnings announcements are timely sources of information for investors. This study presents

\footnotetext{
${ }^{*}$ We would like to thank Eric Noreen (the referee) and Jerold Zimmerman (the editor), whose suggestions led to substantive improvements in the paper. We also appreciate comments received from Victor Bernard, Robert Freeman, William Kinney, Pat O'Brien, John Robinson, and Senyo Tse. Ross Jennings is grateful for the support of the University of Texas at Austin Graduate School of Business. James Noel is grateful for the support of the University of Michigan School of Business Administration.
} 
evidence on whether the disclosure of full financial statements is also a timely source of information.

Financial statement disclosures have been examined in previous research, but the detection of communication value has been limited to specific time periods or to a unique industry disclosure. Wilson (1987) found an association between returns and cash flow from operations at the financial statement release date. Bernard and Stober (1989), however, were unable to extend Wilson's results to other years, even though they found results that are consistent with Wilson's for the time period Wilson studied. More recently, Wahlen (1991) finds some evidence for an association between returns and bank loan loss disclosures for commercial banks at the financial statement release date. While Wilson and Wahlen provide some evidence that disclosure of financial statements can be informative, there is no evidence of systematic communication value of financial statements across time and industry groups.

A major difficulty in evaluating the communication value of financial statements is that the researcher must specify whether the release of the statements is perceived by investors as 'good news' or 'bad news'. Ou and Penman (1989) and Ou (1990) address this problem by using financial statement data to estimate the probability of a future earnings increase. In this study, we use financial statement data to estimate the probability of future financial distress. Previous studies provide evidence that changes in financial distress expectations have significant valuation implications and that the market views increases in financial distress as 'bad news'. Zmijewski (1983) and Burgstahler, Jiambolvo, and Noreen (1989) establish that there is a negative association between unexpected changes in an index of financial distress which is constructed from financial statement information (the probability of bankruptcy) and unexpected returns over the 12 months prior to release of the financial statements. In addition, Thompson, Olsen, and Dietrich (1987) provide direct evidence that financial distress disclosures (Wall Street Journal reports of bankruptcy proceedings, default on debt contracts, and restructuring of loan agreements) have a large negative impact on firm value. For their sample, the mean raw return on the day of the financial distress disclosure is $-3.4 \%$.

Following Zmijewski (1983) and Burgstahler et al. (1989), we use Ohlson's (1980) probability of bankruptcy model to measure financial distress as reflected in the full financial statements. 'I'his bankruptcy model is chosen

\footnotetext{
'Although much information concerning the components of the bankruptcy probability model becomes known through various firm-specific press releases, interim financial statements, and filings with the Securities and Exchange Cornmission throughout the year, there is no systematic and complete disclosure of this information prior to the release of the full financial statements. Consequently, evidence of reaction to changes in the probability of bankruptcy before the annual financial statement disclosures in Zmijewski (1983) and Burgstahler et al. (1989) does not preclude additional communication when the full financial statements are disclosed.
} 
for measuring the impact of the financial statements for several reasons. First, it is based on accounting data that are not trivially available through communication channels that are more timely than accounting reports. Second, Zmijewski (1983) and Foster (1986) indicate that there is little difference in predictive ability between Ohlson's model and competing bankruptcy prediction models. Finally, and in contrast to alternative discriminant function models, Ohlson's logit model has the natural interpretation of a probability of bankruptcy.

The first set of results in this paper provide evidence that noncarnings financial statement data are value-relevant. Excess security returns are cumulated from the beginning of the fiscal year until disclosure of the full financial statements, and then are regressed on contemporaneous revisions in the probability of bankruptcy. The total bankruptcy probability revision is partitioned into a portion which is due to earnings information and a portion which is due to nonearnings information. The results support the existence of a significant association between revisions in the probability of bankruptcy due to nonearnings data and security returns cumulated over this long interval.

The primary test in the paper is for the communication value of nonearnings information during the interval from the announcement of annual earnings through the disclosure of the full financial statements. First, unexpected security returns cumulated over a three-day interval surrounding the financial statement disclosura date are regressed on unexpected changes in the probability of bankruptcy subsequent to the earnings announcement. The results for this interval provide, at best, very weak evidence of a security price reaction due to disclosure of the full financial statements. Second, we conduct a similar test during the period after the firm's annual earnings announcement, but prior to disclosure of the financial statements. For this interval, there is somewhat stronger evidence of leakage of value-relevant nonearnings information. These results, together with the results for the long return interval, suggest that although investors react to the nonearnings disclosures, they have largely revised their estimates of the probability of bankruptcy prior to the release of the full financial statements.

The next section discusses the sample and presents descriptive statistics. Section 3 establishes the value relevance of nonearnings data by testing whether revisions in the bankruptcy index due to nonearnings data are significantly associated with returns during the period from the beginning of the fiscal year through the release of that year's full financial statements. The fourth section presents the primary results of the paper, on the communication value of the annual nonearnings accounting disclosures themselves. Section 5 reports additional analyses which measure the sensitivity of the main results to alternative specifications of the tests. The final section provides concluding remarks. 


\section{Sample selection and descriptive statistics}

The sample consists of firm-years from the period 1978-1984. The beginning of the study period was chosen to avoid overlap with the years used by Ohlson (1980) to estimate the parameters of the bankruptcy prediction model. The study period ends with 1984 because that is the last year for which financial statement disclosure dates are available on the CRSP SEC Filing Date file. Firms with SIC code 6000 or higher are excluded so that the sample is largely from the same industries used by Ohlson to estimate the logit model. ${ }^{2}$ The 1988 version of the Compustat Annual Industrial file has 4,772 firm-years listed on the NYSE and AMEX during 1978-84 with sufficient data to estimate the probahility of bankruptcy at the end of the third and fourth quarters of the current year and at the end of the previous year. Firm-years were eliminated if quarterly earnings announcement dates were not available from Compustat (166 firm-years), if returns were not available from CRSP (157 firm-years), or if the earlier of their annual report or $10-\mathrm{K}$ filing with the SEC was less than six trading days after their annual earnings announcement (74 firm-years). 4,375 firm-years remained in the final sample.

The probability of bankruptcy is estimated each year using actual financial statement data as inputs to Ohlson's (1980) 'one or two years ahead' logit model. Table 1 presents the variable names, logit model coefficient estimates, and variable definitions from Ohlson (1980). Table 2 presents descriptive statistics for our estimates of the probability of bankruptcy using Ohlson's model, for all of the firm-years in our sample. The probability of bankruptcy is generally very low (median of 0.0162 ), and the distribution is skewed to the right as is evidenced by the fact that the mean is more than twice the median. Similar statistics are not reported by Ohlson, but these values are consistent with the results in his fig. 2 (p. 125) for the 'one year ahead' model.'

\section{Valuation relevance of nonearnings data}

\subsection{Hypothesis}

Zmijewski (1983) and Burgstahler et al. (1989) establish that unexpected changes in the probability of bankruptcy are value-relevant, but they do not directly assess whether probability revisions due to the nonearnings compo-

\footnotetext{
${ }^{2}$ Burgstahler et al. (1989) use the same industry criterion.

${ }^{3}$ Burgstahler et al. (1989) report a mean probability of bankruptcy for their sample of 0.0386 based on Ohlson's 'one year ahead' model. Applying the 'one year ahead' model to our sample results in a mean probability of bankruptcy of 0.0193. Burgstahler et al. included Compustat Research firms and OTC firms in their sample, which would tend to raise the probability of bankruptcy relative to our sample.
} 


\section{Table 1}

Variables and coefficient values from Ohlson's (1980) logit model for bankruptcy prediction, 2,163 firms, $1970-1976$. $^{a}$

\begin{tabular}{|c|c|c|}
\hline Variable & $\begin{array}{l}\text { Coeff. est. } \\
(t \text {-stat. })\end{array}$ & Description \\
\hline$S I Z E$ & $\begin{array}{r}-0.478 \\
(-6.23)\end{array}$ & $\begin{array}{l}\text { Log (total assets / GNP price-level index). The index assumes } \\
\text { a base value of } 100 \text { for } 1968 \text {. The index year is as of the year } \\
\text { prior to the year of the balance sheet date. }\end{array}$ \\
\hline$T L T A$ & $\begin{array}{c}5.29 \\
(7.72)\end{array}$ & Total liabilities divided by total assets. \\
\hline$W C T A$ & $\begin{array}{l}-0.99 \\
(-1.74)\end{array}$ & Working capital divided by total assets. \\
\hline$C L C A$ & $\begin{array}{c}0.062 \\
(0.74)\end{array}$ & Current liabilities divided by current assets. \\
\hline NITA & $\begin{array}{l}-4.62 \\
(-3.60)\end{array}$ & Net income divided by total assets. \\
\hline FUTL & $\begin{array}{l}-2.25 \\
(-3.42)\end{array}$ & Funds provided by operations divided by total liabilities. \\
\hline INTWO & $\begin{array}{l}-0.521 \\
(-1.73)\end{array}$ & $\begin{array}{l}\text { One if net income was negative for the last two years, zero } \\
\text { otherwise. }\end{array}$ \\
\hline$O E N E G$ & $\begin{array}{l}-1.91 \\
(-3.11)\end{array}$ & One if total liabilities exceeds total assets, zero otherwise. \\
\hline$C H I N$ & $\begin{array}{r}0.212 \\
(1.30)\end{array}$ & $\begin{array}{l}\left(N I_{t}-N I_{t-1}\right) /\left(\left|N I_{t}\right|+\left|N I_{t-1}\right|\right) \text {, where } N I_{t} \text { is annual net } \\
\text { income for the most recent year and } N I_{t-1} \text { is annual net } \\
\text { income for the previous year. }\end{array}$ \\
\hline CONST & $\begin{array}{c}1.13 \\
(1.15)\end{array}$ & Constant term. \\
\hline
\end{tabular}

"The model is model 3 from Ohlson (1980, table 4, p. 121), which predicts bankruptcy within one or two years.

Table 2

Descriptive statistics for estimated probability of bankruptcy using model 3 from Ohlson (1980), 4,375 firms, $1978-1984$.

\begin{tabular}{lc}
\hline & $\begin{array}{c}\text { Estimated probability } \\
\text { of bankruptcy }\end{array}$ \\
Mean & 0.0413 \\
Standard deviation & 0.0773 \\
Minimum & 0.0000 \\
First quartile & 0.0058 \\
Median & 0.0162 \\
Third quartile & 0.0449 \\
Maximum & 0.9910 \\
\hline
\end{tabular}


nents are value-relevant. ${ }^{4}$ Because earnings affect several components of the bankruptcy index, it is possible that the association of the index with returns is largely explained by the role of unexpected earnings in updating the bankruptcy index. We control for the effect of unexpected earnings on the probability of bankruptcy and directly assess the impact of unexpected changes in nonearnings data. Our null hypothesis is:

$\mathrm{H}_{1}$ : Over the interval from the beginning of the fiscal year through the disclosure of the full financial statements, there is no association between unexpected returns and unexpected changes in the probability of bankruptcy due to changes in nonearnings numbers.

The alternative hypothesis is that there is a negative association between unexpected returns and unexpected changes in the probability of bankruptcy due to nonearnings data.

\subsection{Methodology}

We begin by estimating investor expectations of the probability of bankruptcy $\left(P B_{t}\right)$ at the beginning of the fiscal year. Results in Burgstahler et al. (1989) suggest that the annual time series of $P B_{1}$ is mean-reverting, so that

$$
E_{t-4}\left(P B_{t}\right) \neq P B_{t-4},
$$

where $E(\cdot)$ indicates expectations and time subscripts indicate the end of the relevant quarter. ${ }^{5}$ Therefore, we use the following regression to estimate the beginning-of-year expectation for firm $i$ in year $t$ :

$$
P B_{i, t}=a+b P B_{i, t-4}+e_{i, t} \text {. }
$$

Estimates of $a$ and $b$, based on pooled cross-sectional time-series data, are used to compute the expected value of $P B_{i, t}$ for firm $i$ based on the information known at the beginning of the year. ${ }^{6}$

$$
E_{t-4}\left(P B_{i, t}\right)=0.0140+0.6687 P B_{i, t-4},
$$

\footnotetext{
${ }^{4}$ Burgstahler et al. (1989) do explicitly control for the effect of unexpected earnings in their test of the relation between security returns and changes in the probability of bankruptcy. However, they do not explicitly control for the effect of earnings on the probability measure. We attempt to do that, and thereby isolate the effect of nonearnings information on the probability measure.

${ }^{5}$ Although not necessary for this section, quarterly data will be used in the next section, and this notation will maintain consistency between the two sections.

${ }^{6}$ Because the regression uses realized values in estimating expectations, the expectations are based on hindsight. The adjusted $R^{2}$ for this regression is 0.427 based on 4,375 observations. The $t$-statistics for $a$ and $b$ are 7.48 and 12.19 , respectively. All regression $t$-statistics reported in the paper are based on White's (1980) covariance estimator.
} 
so that the total estimated unexpected change in the probability of bankruptcy during year $t$ for firm $i$ is

$$
\Delta P B_{i, t}=P B_{i, t}-E_{t-4}\left(P B_{i, t}\right)=e_{i, t} .
$$

The unexpected change in the probability of bankruptcy must be decomposed into the change which is due to unexpected nonearnings data and the change which is due to unexpected earnings. We partition the independent variables in Ohlson's probability of bankruptcy model into those that directly reflect earnings information, which we denote $E$, and those that do not, which we denote $N E .^{7}$ Thus, the probability of bankruptcy based on the full financial statements for firm $i$ from quarter $t$ can be written as

$$
P B_{i, t}=P B\left(E_{i, t}, N E_{i, t}\right)
$$

We then partition the unexpected change in the probability of bankruptcy into the portion due to nonearnings data $(\triangle P B N E)$ and the portion due to earnings data $(\triangle P B E)$ such that

$$
\Delta P B_{i, t}=\Delta P B N E_{i, t}+\Delta P B E_{i, t},
$$

where

$$
\triangle P B N E_{i, t}=P B\left(E_{i, t}, N E_{i, t}\right)-P B\left(E_{i, t}, N E_{i, t-4}\right)
$$

and

$$
\Delta P B E_{i, t}=P B\left(E_{i, t}, N E_{i, t-4}\right)-E_{t-4}\left(P B_{i, t}\right)
$$

The Spearman rank order correlation between $\triangle P B E$ and $\triangle P B N E$ for our sample is 0.025 , which indicates that the earnings and nonearnings portions of the unexpected change in the prubability of bankruptcy are not highly correlated.

The test for an association between security returns and revisions in the probability of bankruptcy due to nonearnings data is based on the following regression:

$$
U R_{i, F Y}=c_{0}+c_{1} U E_{i, t}+c_{2} \Delta P B E_{i, t}+c_{3} \Delta P B N E_{i, t}+u_{i, t},
$$

where $U R_{i, F Y}$ is unexpected returns cumulated from the beginning of the year until four days after the earlier of firm $i$ 's annual report or $10-\mathrm{K}$ filing

\footnotetext{
${ }^{7}$ The earnings variables $(E)$ are INTWO, CHIN, and the numerator of NITA. The nonearnings variables (NE) are SIZE, TLTA, WCTA, CLCA, FUTL, OENEG, and the denominator of $N I T A$. See table 1 for variable definitions.
} 
with the SEC for year $t .{ }^{8} U E_{i, t}$ is unexpected earnings for firm $i$ in year $t$, which is included as a control for the relation between unexpected earnings and unexpected returns during the interval. $U E_{i, t}$ is specified as the difference between actual earnings per share before discontinued operations and extraordinary items for year $t$ and the previous year, deffated by the security price at the beginning of year $t$.

The test of the null hypothesis focuses on $c_{3}$ from eq. (1), the coefficient on the unexpected change in the probability of bankruptcy due to nonearnings data, $\triangle P B N E$. The null hypothesis is $c_{3}-0$, and the alternative is $c_{3}<0$. The regression is estimated using 4,375 firm-years, which have a median return interval of 317 trading days and a maximum (minimum) interval of 588 (276) trading days. ${ }^{9}$

\subsection{Results}

The results of the estimation of eq. (1) for all firm-years in the sample are reported in the first row of table 3 . The coefficient on $\triangle P B N E$ is negative, as predicted, and significant $(t=-2.65){ }^{10}$ This supports the hypothesis that the nonearnings information disclosed during this return interval is useful to investors in revising their expectations of the probability of bankruptey. Also consistent with expectations, the coefficient on $\triangle P B E\left(c_{2}\right)$ is negative and significant $(t=-3.00)$, and the coefficient on $U E\left(c_{1}\right)$ is positive and significant $(t=5.77) .{ }^{11}$

To determine the effect on the results of the small number of firms with large changes in their probability of bankruptcy, we successively trimmed firm-years with extreme values of $\triangle P B$ from the sample. The second, third, and fourth sets of results reported in table 3 are for reduced samples when 2 percent, 10 percent, and 20 percent of the sample are deleted. In general, the effect of trimming 2 and 10 percent of the sample is to raise the significance of all of the independent variables. In particular, the coefficient on $\triangle P B N E$

\footnotetext{
${ }^{8}$ Unexpected returns are computed using a procedure that adjusts each firm's return for the mean return of firms of comparable size. To do this, all firms on the American and New York Stock Exchanges are divided into ten groups each year on the basis of their market value of equity on the last day of the preceding year. For each day, the unexpected return for each firm is the difference between the raw return of the firm and the mean return that day of the size portfolio of which that firm is a member. Daily returns are then compounded.

${ }^{9}$ The 588-day interval is for the Lioncl Corporation's fiscal ycar ending December 31, 1981. Lionel filed for bankruptcy under Chapter 11 in February, 1982, and did not file their $10-\mathrm{K}$ for 1981 until April 22, 1983. Only 16 firm-years have a return interval longer than 350 days.

${ }^{10}$ Recall that all $t$-statistics reported in the paper are based on White's (1980) covariance estimator.

${ }^{11}$ Note that the firm-years overlap, so that the observations cannot be viewed as independent. To assess the effect of this dependence, we re-estimated the regression separately for odd and even numbered years. The results for both subsamples were qualitatively the same as those for the full sample.
} 
Table 3

Regression tests of relation between excess returns and unexpected changes in the probability of bankruptcy, fiscal year, 4,375 firms, 1978-1984. ${ }^{\mathrm{a}}$

Model: $\quad U R_{i, F Y}=c_{0}+c_{1} U E_{i, t}+c_{2} \Delta P B E_{i, t}+c_{3} \Delta P B N E_{i, t}+u_{i, t}$

\begin{tabular}{|c|c|c|c|c|c|}
\hline$c_{0}$ & $c_{1}$ & $c_{2}$ & $c_{3}$ & Adj. $R^{2}$ & $\bar{N}$ \\
\hline \multicolumn{6}{|c|}{ All firm-years } \\
\hline $\begin{array}{r}-0.025 \\
(-4.02) \\
(0.00)\end{array}$ & $\begin{array}{c}0.404 \\
(5.77) \\
(0.00)\end{array}$ & $\begin{array}{r}-1.491 \\
(-3.00) \\
(0.00)\end{array}$ & $\begin{array}{r}-0.850 \\
(-2.65) \\
(0.00)\end{array}$ & 0.084 & 4375 \\
\hline \multicolumn{6}{|c|}{2 percent trimmed from sample based on extreme values of $\triangle P B$} \\
\hline $\begin{array}{r}-0.032 \\
(-5.76) \\
(0.00)\end{array}$ & $\begin{array}{c}0.558 \\
(6.27) \\
(0.00)\end{array}$ & $\begin{array}{r}-2.583 \\
(-7.78) \\
(0.00)\end{array}$ & $\begin{array}{r}-1.028 \\
(-3.08) \\
(0.00)\end{array}$ & 0.080 & 4289 \\
\hline
\end{tabular}

10 percent trimmed from sample based on extreme values of $\triangle P B$

$-0.052$

$(-8.47)$

1.039

(9.50)

$-4.650$

$-1.751$

0.119

3939

(0.00)

(0.00)

$(-9.90)$

$(-2.92)$

$(0.00)$

20 percent trimmed from sample based on extreme values of $\triangle P B$

\begin{tabular}{rrrr}
-0.063 & 1.101 & -5.044 & -1.156 \\
$(-7.80)$ & $(8.27)$ & $(-6.80)$ & $(-1.16)$ \\
$(0.00)$ & $(0.00)$ & $(0.00)$ & $(0.12)$ \\
& \multicolumn{4}{r}{ Extreme 20 percent of sample based } \\
-0.003 & 0.207 & -1.225 & -1.145 \\
$(-0.16)$ & $(4.08)$ & $(-1.96)$ & $(-3.64)$ \\
$(0.87)$ & $(0.00)$ & $(0.03)$ & $(0.00)$
\end{tabular}

$0.105 \quad 3501$

All firm-years, all independent variables ranked

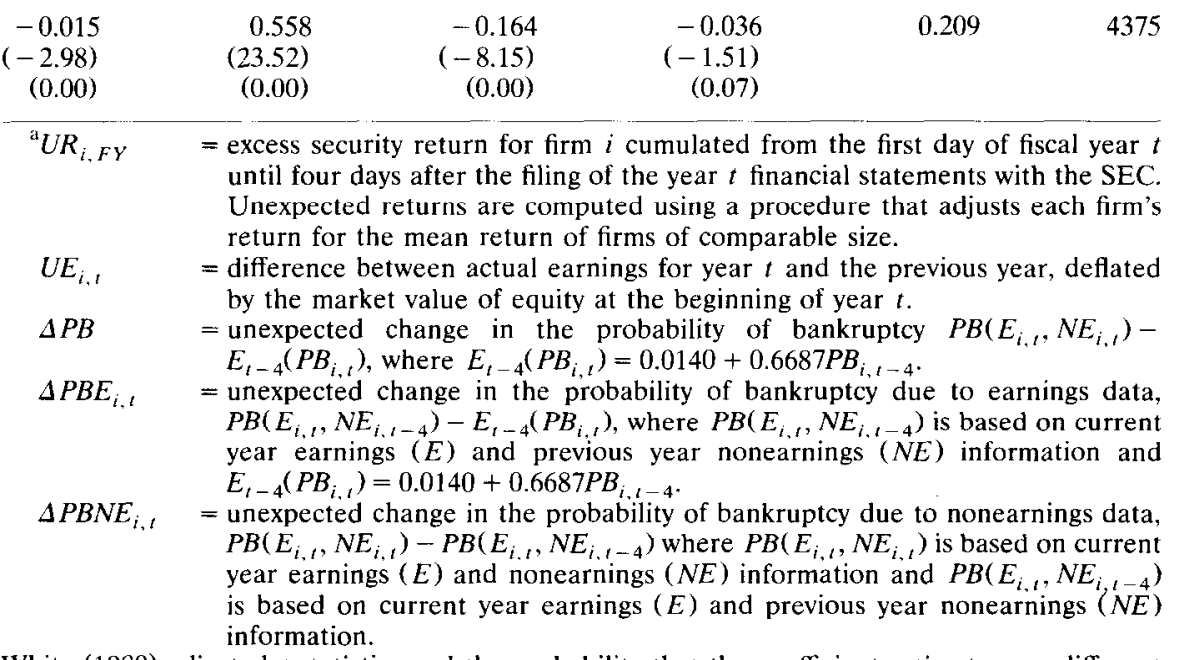

White (1980) adjusted $t$-statistics and the probability that the coefficient estimates are different from zero are reported in parentheses. Probability values are based on two-sided tests for the intercept and one-sided tests for the slope coefficients. 
continues to be significantly negative for these two reduced samples. However, when the sample is reduced by 20 percent, the coefficient on $\triangle P B N E$ is no longer significant at conventional levels. This indicates that the significant results for $\triangle P B N E$ for the full sample are due mainly to firms with large unexpected changes in the probability of bankruptcy.

To examine the relation between security returns and changes in the probability more closely when the change in the probability of bankruptcy is large, we re-estimated eq. (1) for the extreme 20 percent of the sample based on $\triangle P B$. The results for this subsample are reported in table 3 . The coefficients on both $\triangle P B E$ and $\triangle P B N E$ are negative and significant, indicating a strong relation between changes in probability of bankruptcy and security returns for this subsample. ${ }^{12}$

The final set of results in table 3 is for the full sample with percentile ranks of the independent variables replacing their magnitudes. These percentile ranks are adjusted for the mean, resulting in a range of values between -0.5 and 0.5 . This specification reduces the influence of extreme observations for all of the independent variables in the regression. There are several differences between the results of this ranked regression and the results for the full sample when the independent variables are not ranked. First, the explanatory power of the ranked regression is more than twice that for the comparable unranked regression, which indicates a nonlinear relation between security returns and some of the independent variables in the unranked regression. Second, the coefficients on $U E$ and $\triangle P B E$ are much more significant in the ranked regression. This indicates that the relation between returns and these variables is not linear over the whole range. Finally, the coefficient on $\triangle P B N E$ is much less significant in the ranked regression, indicating that part of its explanatory power in the unranked regression is to compensate for the nonlinear relations between returns and $U E$ and $\triangle P B E$. However, even after taking this into consideration, the coefficient on $\triangle P B N E$ in the ranked regression is still negative and significant at the 10 percent level. ${ }^{13}$

\footnotetext{
${ }^{12}$ Note that this subsample also has a very high level of probability of bankruptcy. The mean beginning-of-period probability $\left(P B_{i, t-4}\right)$ is 0.112 , which is considerably higher than the mean for the entire sample $(0.0413)$.

${ }^{13}$ To determine the sensitivity of our results to the decomposition of the unexpected change in the probability of bankruptcy into earnings and nonearnings components, we repeated the analysis reversing the order of the updating of earnings and nonearnings information in revisions in the probability of bankruptcy. To do this, we let $\triangle P B E_{i, 2}=P B\left(E_{i, t}, N E_{i, t}\right)-P B\left(E_{i, t}, N E_{i, t}\right)$ and $\triangle P B N E_{i, t}=P B\left(E_{i, t-4}, N E_{i, t}\right)-E_{i, t-4}\left(P B_{t}\right)$. This alternative decomposition increased the significance of $\triangle P B N E_{i, t}$ (the lowest $t$-statistic was -4.97 ) and decreased the significance of $\triangle P B E_{i, t}$ in the regressions reported in table 3 . The conclusion that nonearnings data are significant is more strongly supported using this alternative decomposition.
} 
To gain insight into the relation between changes in the probability of bankruptcy and security returns, table 4 reports excess returns for the same interval used in table 3 for portfolios formed on the basis of $U E, \triangle P B E$, and $\triangle P B N E$. Two analyses are reported in table 4 . The first analysis, in panel $\mathrm{A}$, reports returns for portfolios formed by separately partitioning firms into 'good news' and 'bad news' portfolios on the basis of each of the three variables $U E, \triangle P B E$, and $\triangle P B N E$. Specifically, firm-years are placed in the 'good news' portfolio if $U E$ ( $\triangle P B E$ or $\triangle P B N E$ ) is above (below) the sample median. The difference in returns between the two portfolios reflects the return from investing long in firms for which the relevant variable indicates 'good news' and short in firms for which the relevant variable indicates 'bad news'. The second analysis in table 4 (panel B) reports results for portfolios based on 'good news' and 'bad news' for $\triangle P B N E$ after controlling for $U E$ and $\triangle P B E$.

For both analyses, returns are cumulated for the full return interval as well as for three subsets of the full return interval. The first subset is the interval from the beginning of the fiscal year through two days before the annual earnings announcement, excluding three-day intervals centered around each of the quarterly earnings announcements. The second subset consists of the four three-day intervals centered on each of the quarterly earnings announcements. The final subset is the interval from two days after the annual earnings announcement to four days after the SEC financial report filing. ${ }^{14}$ Table 4 permits evaluation of whether most of the association between security returns and changes in the probability of bankruptcy is due only to intervals immediately surrounding earnings announcements, or whether such an association also occurs during other times of the year.

In panel $\mathrm{A}$ of table 4 , the results for $U E$ are similar to those reported in Ball and Brown (1968). The annual return difference between firms classified as 'good news' and those classified as 'bad news' based on unexpected earnings is nearly 30 percent. For classifications based on $\triangle P B E$ and $\triangle P B N E$, the return differences are 9.2 percent and 12.2 percent, respectively, considerably smaller than for unexpected earnings but still significant at the 0.01 level. All three variables are significantly associated with security returns throughout the year, both during yuarterly earnings announcements and nonannouncement periods. However, none of the return differences for the interval after the annual earnings announcement are significantly different from zero.

\footnotetext{
${ }^{14}$ While there are three quarterly financial statement releases during the year which are included in the nondisclosure windows, we would not expect those disclosure events to be significant if the annual financial statement release event is not. Thus, additional analysis of the quarterly financial statement releases is warranted only if we find something at the annual financial statement release date.
} 
Table 4

Cumulative excess returns for portfolios formed on the basis of $U E_{i, \ell}, \triangle P B E_{i, \ell}$, and $\triangle P B N E_{i, \ell}$, 4,375 firms, $1978-1984$. $^{\mathrm{a}}$

\begin{tabular}{|c|c|c|c|c|c|c|}
\hline \multirow[b]{2}{*}{ Portfolio ${ }^{b}$} & \multirow[b]{2}{*}{$N$} & \multirow[b]{2}{*}{$\begin{array}{c}\text { Mean } \\
\triangle P B N E\end{array}$} & \multicolumn{4}{|c|}{ Mean excess returns ${ }^{c}$} \\
\hline & & & $\begin{array}{c}\text { Pre-EA } \\
\text { days }\end{array}$ & $\begin{array}{l}E A \\
\text { days }\end{array}$ & $\begin{array}{l}\text { Post-EA } \\
\text { days }\end{array}$ & Total \\
\hline $\begin{array}{l}U E \text { - 'good' } \\
U E \text { - 'bad' }\end{array}$ & $\begin{array}{l}2186 \\
2189\end{array}$ & $\begin{array}{r}-0.006 \\
0.012\end{array}$ & $\begin{array}{r}0.083 \\
-0.133\end{array}$ & $\begin{array}{r}0.047 \\
-0.031\end{array}$ & $\begin{array}{l}0.003 \\
0.000\end{array}$ & $\begin{array}{r}0.133 \\
-0.164\end{array}$ \\
\hline $\begin{array}{l}\text { Difference } \\
(t \text {-statistic) } \\
\text { (probability level) }\end{array}$ & & $\begin{array}{r}-0.018 \\
(-12.02) \\
(0.00)\end{array}$ & $\begin{array}{r}0.216 \\
(21.81) \\
(0.00)\end{array}$ & $\begin{array}{r}0.078 \\
(23.45) \\
(0.00)\end{array}$ & $\begin{array}{r}0.003 \\
(0.69) \\
(0.25)\end{array}$ & $\begin{array}{r}0.297 \\
(27.15) \\
(0.00)\end{array}$ \\
\hline $\begin{array}{l}\triangle P B E \text { - 'good' } \\
\triangle P B E \text { - 'bad' }\end{array}$ & $\begin{array}{l}2186 \\
2189\end{array}$ & $\begin{array}{r}-0.000 \\
0.006\end{array}$ & $\begin{array}{r}0.018 \\
-0.069\end{array}$ & $\begin{array}{l}0.011 \\
0.005\end{array}$ & $\begin{array}{l}0.001 \\
0.002\end{array}$ & $\begin{array}{r}0.030 \\
-0.062\end{array}$ \\
\hline $\begin{array}{l}\text { Difference } \\
\text { ( } t \text {-statistic) } \\
\text { (probability level) }\end{array}$ & & $\begin{array}{r}-0.006 \\
(-4.10) \\
(0.00)\end{array}$ & $\begin{array}{r}0.087 \\
(8.40) \\
(0.00)\end{array}$ & $\begin{array}{l}0.006 \\
(1.90) \\
(0.03)\end{array}$ & $\begin{array}{r}-0.001 \\
(-0.40) \\
(0.66)\end{array}$ & $\begin{array}{r}0.092 \\
(7.78) \\
(0.00)\end{array}$ \\
\hline $\begin{array}{l}\triangle P B N E \text { - 'good' } \\
\triangle P B N E \text { - 'bad' }\end{array}$ & $\begin{array}{l}2186 \\
2189\end{array}$ & $\begin{array}{r}-0.013 \\
0.019\end{array}$ & $\begin{array}{r}0.020 \\
-0.071\end{array}$ & $\begin{array}{r}0.025 \\
-0.009\end{array}$ & $\begin{array}{l}0.000 \\
0.003\end{array}$ & $\begin{array}{r}0.045 \\
-0.077\end{array}$ \\
\hline $\begin{array}{l}\text { Difference } \\
\text { ( } t \text {-statistic) } \\
\text { (probability level) }\end{array}$ & & $\begin{array}{r}-0.032 \\
(-21.89) \\
(0.00)\end{array}$ & $\begin{array}{r}0.091 \\
(8.81) \\
(0.00)\end{array}$ & $\begin{array}{r}0.034 \\
(9.76) \\
(0.00)\end{array}$ & $\begin{array}{r}-0.003 \\
(-1.10) \\
(0.86)\end{array}$ & $\begin{array}{r}0.122 \\
(10.40) \\
(0.00)\end{array}$ \\
\hline
\end{tabular}

In panel $B$ of table 4 , firm-years are assigned to one of eight portfolios depending on whether $U E, \triangle P B E$, and $\triangle P B N E$ indicate 'good news' (G) or 'bad news' (B) for that year. For example, a firm-year that is above the median $U E$, below the median $\triangle P B E$, and above the median $\triangle P B N E$ is assigned to portfolio GGB. For each pair of $U E-\triangle P B E$ control portfolios (GG, GB, BG, BB), table 4 presents both cumulated returns and return differences for firm-years that are 'good news' $(G)$ and 'bad news' (B) on the basis of $\triangle P B N E$. When the two earnings variables both indicate 'good news', there is no apparent association between $\triangle P B N E$ and returns after controlling for $U E$ and $\triangle P B E$; the return difference between GGG and GGB is -0.5 percent, which is not significantly different from zero. However, when one or both of the earnings variables indicates 'bad news' there is an association between $\triangle P B N E$ and returns. For example, the return difference between the BBG and BBB portfolios is 9.4 percent, which is significant at the 0.01 level. Similarly, the differences between the GBG and GBB portfolios (4.9 percent) and between the BGG and BGB portfolios (5.1 percent) are significant at the 0.06 level and the 0.01 level, respectively. This indicates that investors may use nonearnings data to interpret 'bad' earnings news, but that nonearnings data are less useful for interpreting 'good' earnings news. 
Table 4 (continued)

Panel B: 'Good' and 'bad' news portfolios formed on the basis of $\triangle P B N F_{i,}$ after controlling for $U E_{i, t}, \triangle P B E_{i, t}$

\begin{tabular}{|c|c|c|c|c|c|c|}
\hline \multirow[b]{2}{*}{$\begin{array}{l}\text { Portfolio }^{\text {d }} \\
(U E, \triangle P B E, \triangle P B N E)\end{array}$} & \multirow[b]{2}{*}{$N$} & \multirow[b]{2}{*}{$\begin{array}{c}\text { Mean } \\
\triangle P B N E\end{array}$} & \multicolumn{4}{|c|}{ Mean excess returns ${ }^{c}$} \\
\hline & & & $\begin{array}{l}\text { Pre-EA } \\
\text { days }\end{array}$ & $\begin{array}{l}E A \\
\text { days }\end{array}$ & $\begin{array}{l}\text { Post } E A \\
\text { days }\end{array}$ & Total \\
\hline GGG & 690 & -0.007 & 0.119 & 0.041 & -0.002 & 0.158 \\
\hline GGB & 438 & 0.005 & 0.122 & 0.037 & 0.004 & 0.163 \\
\hline $\begin{array}{l}\text { Difference } \\
\text { ( } t \text {-statistic) } \\
\text { (probability level) }\end{array}$ & & $\begin{array}{r}-0.012 \\
(-9.99) \\
(0.00)\end{array}$ & $\begin{array}{r}-0.003 \\
(-0.11) \\
(0.55)\end{array}$ & $\begin{array}{r}0.004 \\
(0.68) \\
(0.25)\end{array}$ & $\begin{array}{r}-0.006 \\
(-0.94) \\
(0.83)\end{array}$ & $\begin{array}{r}-0.005 \\
(-0.20) \\
(0.58)\end{array}$ \\
\hline GBG & 682 & -0.027 & 0.049 & 0.069 & 0.003 & 0.121 \\
\hline GBB & 379 & 0.019 & 0.031 & 0.032 & 0.009 & 0.072 \\
\hline $\begin{array}{l}\text { Diffcrencc } \\
\text { ( } t \text {-statistic) } \\
\text { (probability level) }\end{array}$ & & $\begin{array}{r}-0.046 \\
(-15.40) \\
(0.00)\end{array}$ & $\begin{array}{r}0.018 \\
(0.73) \\
(0.23)\end{array}$ & $\begin{array}{r}0.037 \\
(4.57) \\
(0.00)\end{array}$ & $\begin{array}{r}-0.006 \\
(-0.86) \\
(0.81)\end{array}$ & $\begin{array}{r}0.049 \\
(1.52) \\
(0.06)\end{array}$ \\
\hline $\begin{array}{l}\text { BGG } \\
\text { BGB }\end{array}$ & $\begin{array}{l}433 \\
625\end{array}$ & $\begin{array}{r}-0.002 \\
0.004\end{array}$ & $\begin{array}{l}-0.058 \\
-0.113\end{array}$ & $\begin{array}{l}-0.017 \\
-0.019\end{array}$ & $\begin{array}{r}-0.002 \\
0.004\end{array}$ & $\begin{array}{l}-0.077 \\
-0.128\end{array}$ \\
\hline $\begin{array}{l}\text { Difference } \\
\text { ( } t \text {-statistic) } \\
\text { (probability level) }\end{array}$ & & $\begin{array}{r}-0.006 \\
(-10.84) \\
(0.00)\end{array}$ & $\begin{array}{r}0.055 \\
(3.80) \\
(0.00)\end{array}$ & $\begin{array}{l}0.002 \\
(0.53) \\
(0.30)\end{array}$ & $\begin{array}{r}-0.006 \\
(-1.30) \\
(0.90)\end{array}$ & $\begin{array}{l}0.051 \\
(3.25) \\
(0.00)\end{array}$ \\
\hline $\begin{array}{l}\text { BBG } \\
\text { BBB }\end{array}$ & $\begin{array}{l}381 \\
747\end{array}$ & $\begin{array}{r}-0.012 \\
0.038\end{array}$ & $\begin{array}{l}-0.121 \\
-0.200\end{array}$ & $\begin{array}{l}-0.034 \\
-0.048\end{array}$ & $\begin{array}{r}0.000 \\
-0.001\end{array}$ & $\begin{array}{l}-0.155 \\
-0.249\end{array}$ \\
\hline $\begin{array}{l}\text { Difference } \\
\text { ( } t \text {-statistic) } \\
\text { (probability level) }\end{array}$ & & $\begin{array}{r}-0.050 \\
(-13.95) \\
(0.00)\end{array}$ & $\begin{array}{r}0.079 \\
(4.56) \\
(0.00)\end{array}$ & $\begin{array}{r}0.014 \\
(2.14) \\
(0.02)\end{array}$ & $\begin{array}{r}0.001 \\
(0.20) \\
(0.42)\end{array}$ & $\begin{array}{r}0.094 \\
(4.96) \\
(0.00)\end{array}$ \\
\hline
\end{tabular}

${ }^{a} U E_{i, t} \quad=$ difference between actual earnings for year $t$ and the previous year, deflated by the market value of equity at the beginning of year $t$.

$\triangle P B E_{i, t}=$ unexpected change in the probability of bankruptcy due to earnings data, $P B\left(E_{i, t}, N E_{i, t-4}\right)-E_{t-4}\left(P B_{i, t}\right)$, where $P B\left(E_{i, t}, N E_{i, t-4}\right)$ is based on current year earnings $(E)$ and previous year nonearnings $(N E)$ information and $E_{t-4}\left(P B_{i, t}\right)=0.0140+0.6687 P B_{i, t-4}$.

$\triangle P B N E_{i,}=$ unexpected change in the probability of bankruptcy due to nonearnings data, $P B\left(E_{i, t}, N E_{i, t}\right)-P B\left(E_{i, t}, N E_{i,-4}\right)$, where $P B\left(E_{i, t}, N E_{i, t}\right)$ is based on current year earnings $(E)$ and nonearnings $(N E)$ information and $P B\left(E_{i, t}, N E_{i, t-4}\right)$ is based on current year earnings $(E)$ and previous year nonearnings $(N E)$ information.

White (1980) adjusted $t$-statistics and the probability that the portfolio return differences are different from zero are reported in parentheses. Probability values are based on one-sided tests for the portfolio return differences.

${ }^{\text {h}}$ Portfolios are formed on the basis of whether $U E, \triangle P B E$, and $\triangle P B N E$ are above or below the sample median, respectively. The portfolio is 'good' news when $U E$ ( $\triangle P B E$ or $\triangle P B N E$ ) is above (below) the sample median.

${ }^{\mathrm{c}}$ Excess returns are cumulated from the beginning of the fiscal year until four days after the SEC disclosure date (Total). Three subsets of this return interval are also reported: the four three-day intervals surrounding each of the quarterly earnings announcements ( $E A$ days, length equals 12 trading days), four intervals preceding each of the quarterly earnings announcement intervals (Pre-EA days, median length equals 273 trading days), and the interval from two days after the annual earnings announcement until four days after the SEC disclosure date (Post-EA days, median length equals 29 trading days). Excess returns are computed using a procedure that adjusts each firm's return for the mean return of firms of comparable size.

${ }^{\mathrm{d}}$ Portfolios are formed on the basis of whether $U E, \triangle P B E$, and $\triangle P B N E$ are above or below the sample median, respectively. The portfolio is 'good' news when $U E$ ( $\triangle P B E$ or $\triangle P B N E$ ) is above (below) the sample median. For example, firm-years in portfolio GGB are above the median for $U E$, below the median for $\triangle P B E$, and above the median for $\triangle P B N E$. 
The timing of portfolio returns is also affected by the type of earnings news. When $U E$ indicates 'bad news', very little of the return difference accompanies the quarterly earnings announcements. For the two $U E$ 'bad news' portfolio differences reported in table 4 , panel $\mathrm{B}$, the average return difference during the quarterly earnings announcements was only about 12 percent of the return difference during the remainder of the fiscal year. In contrast, for the two $U E$ 'good news' portfolio differences, the average return difference during the quarterly earnings announcements was larger than the return difference during the remainder of the fiscal ycar. This indicates that when $U E$ indicates 'bad news', nonearnings news is not being inferred from earnings announcements, but is being communicated through other means.

Based on the results in tables 3 and 4 , there is a significant association between the unexpected probability of bankruptcy due to nonearnings information, and unexpected returns. However, table 4 reports no significant association during the period subsequent to the annual earnings announcement for either analysis, indicating little impact due to the disclosure of the financial statements. In panel $A$ of table 4 , the return difference for this interval for $U E$ is only 0.3 percent, and the return differences for $\triangle P B E$ and $\triangle P B N E$ are both small and negative. Similarly, in panel $\mathrm{B}$ of table 4 there is little indication of an association between security returns and disclosure of the full financial statements. Three of the return differences for the interval following the annual earnings announcement are in the wrong direction, and the fourth is only 0.1 percent. It is possible that the lack of association is partially due to the lack of power in the methodology, particularly because the date of disclosure is not specified precisely, and also because the expected probability of bankruptcy becomes more outdated as the year progresses. In the next section, we perform a more powerful test of the disclosure impact of the financial statements by identifying dates more precisely, and incorporating more current information into the expectations model for the probability of bankruptcy around the date of the financial statements release.

\section{Communication of nonearnings data}

\subsection{Hypothesis}

Our objective is to determine the communication value of nonearnings accounting disclosures. To do this, we test for an association between unexpected changes in the probability of bankruptcy and unexpected returns for the three-day interval beginning the day before receipt by the SEC of 
each firm's annual report or $10-\mathrm{K}$, whichever is earlier. ${ }^{15}$ This return interval is referred to as the SEC interval. ${ }^{16}$

We also examine the period from the day after the earnings announcement until two days before the earlier of the firm's annual report or $10-\mathrm{K}$ filing with the SEC. ${ }^{17}$ Disclosure may occur during this interim interval if nonearnings information leaks to the market between the announcement of annual earnings and disclosure of the full financial statements. This leakage could result from other press releases, early reports mailed to shareholders, contacts between analysts and the company, or insider trading. ${ }^{18}$

For both the SEC interval and the interim interval, we investigate the following hypothesized association between changes in the probability of bankruptcy and security returns:

$\mathrm{H} 2_{0}$ : There is no association between unexpected security returns and unexpected changes in the probability of bankruptcy due to nonearnings data.

The alternative hypothesis is that there is a negative association between unexpected security returns and unexpected changes in the probability of bankruptcy.

\subsection{Methodology}

To test $\mathrm{H}_{2}$, we must estimate investors' expectations immediately after the earnings announcement, but prior to the SEC disclosure date. Three types of data are used to form expectations: (a) the probability of bankruptcy based on last year's financial statement data $P B\left(E_{i, t-4}, N E_{i, t-4}\right)$, (b) the

${ }^{15}$ The results for longer (five-day and nine-day) intervals are discussed below.

${ }^{16}$ SEC filing dates were retrieved from the Center for Research in Security Prices SEC Filing Date file. For 732 of the 4,375 firm-years in our sample, only one annual report or $10-\mathrm{K}$ filing date is available on the CRSP SEC data base. For the 3,643 firm-years in our sample that have both filing dates, 1,728 (47 percent) filed their amnual report first, 438 (12 percent) filed their annual report and $10-\mathrm{K}$ on the same date, and 1,477 (41 percent) filed their $10-\mathrm{K}$ first. In addition, 1,337 ( 37 percent) filed their annual report within five days of their 10-K.

${ }^{17}$ For this interval, we wish to specifically exclude the actual release of the financial statements. Using the earlier of the $10-\mathrm{K}$ filing and the receipt of the annual report at the SEC accomplishes this.

${ }^{18}$ To learn more about the sequence of firm disclosures, we sent a survey to 646 firms, a randomly selected subset of our sample. We received 212 usable responses. Of the responses to our survey, 78 ( 37 percent) firms indicated that they provide financial statements to shareholders or analysts/brokers more than three days before mailing their 10-K to the SEC. An additional 35 (17 percent) firms indicated that, upon request, they provide analysts with actual account balances before disclosure of the full financial statements. Bernard and Stober (1989) report that 27 percent of a sample of firms that responded to a written request indicated that 'they typically mail a separate fourth-quarter report to shareholders prior to mailing the annual report' (footnote 16, p. 632). 
probability of bankruptcy based on third-quarter financial statement data $P B\left(E_{i, t-1}, N E_{i, t-1}\right)$, and (c) the probability of bankruptcy based on the most recent set of information, nonearnings data from the third-quarter financial statements and actual earnings for the current year $P B\left(E_{i, t}, N E_{i, t-1}\right){ }^{19}$ These variables are used to estimate the expected probability of bankruptcy after the earnings announcement, denoted $F_{E A}\left(P B_{i, d}\right)$, using the following regression:

$$
\begin{aligned}
P B_{i, t}= & a+b_{1} P B\left(E_{i, t-4}, N E_{i, t-4}\right)+b_{2} P B\left(E_{i, t-1}, N E_{i, t-1}\right) \\
& +b_{3} P B\left(E_{i, t}, N E_{i, t-1}\right)+e_{i, t} .
\end{aligned}
$$

Estimates of $a, b_{1}, b_{2}$, and $b_{3}$, based on pooled cross-sectional time-series data, are used to compute the expected value of $P B_{i, t}$ for firm $i$ based on the information known at the earnings announcement: ${ }^{20}$

$$
\begin{aligned}
E_{E A}\left(P B_{i, t}\right)= & -0.0008+0.0445 P B\left(E_{i, t-4}, N E_{i, t-4}\right) \\
& -0.2964 P B\left(E_{i, t-1}, N E_{i, t-1}\right) \\
& +1.2646 P B\left(E_{i, t}, N E_{i, t-1}\right) .
\end{aligned}
$$

The new information reflected in the full financial statements is then computed as

$$
\triangle P B F S_{i, t}=P B\left(E_{i, t}, N E_{i, t}\right)-E_{E A}\left(P B_{i, t}\right)=e_{i, t} .
$$

The main result of the paper is to test for an association between unexpected returns and unexpected revisions in the probability of bankruptcy at disclosure of the full financial statements. These tests are conducted with the following regression: ${ }^{21}$

$$
U R_{i,(S E C-1, S E C+1)}=c_{0}+c_{1} \Delta P B F S_{i, t}+u_{i, t},
$$

\footnotetext{
${ }^{19}$ Our partition of the independent variables in Ohlson's bankruptcy model into earnings $(E)$ and nonearnings $(N E)$ components is the same as discussed earlier in footnote 7 . Note that $E_{i, t}$ must be an annual earnings number for use in the bankruptcy index. Therefore, it is computed as total earnings for quarters $t-1$ through $t-5 . N E_{i, t-1}$ are actual third-quarter data for all of the nonearnings components of the bankruptcy index except funds provided by operations, which was not generally disclosed on a quarterly basis during our sample period. Funds provided by operations is estimated by adjusting the relevant earnings variable (either $E_{i, t-1}$ or $E_{i, l}$ ) by the mean nonfund accruals for the previous five years.

${ }^{20}$ Because the regression uses realized values in estimating expectations, the expectations are based on hindsight. The adjusted $R^{2}$ for this regression is 0.911 based on 4,375 observations. The $t$-statistics for $a, b_{1}, b_{2}$, and $b_{3}$ are $-1.03,1.25,-2.92$, and 15.71 , respectively.

${ }^{21} \mathrm{It}$ is possible that there is a relationship between unexpected returns and unexpected earnings during either the SEC interval or the interim interval that is due to post earnings announcement drift [see Bernard and Thomas (1989)]. We also estimated the regression with unexpected income included to control for post earnings announcement drift. This had no significant effect on the results.
} 
where $U R_{i,(S E C-1, S E C+1)}$ is unexpected security returns for firm $i$ cumulated from the day before until the day after the SEC disclosure date. Eq. (2) is also used to test $\mathrm{H} 2{ }_{0}$ over the earlier interim interval, between the earnings announcement and the financial statement disclosure date. For this interval, returns are cumulated from two days after the earnings announcement until two days before the earliest SEC disclosure date $(E A+2, S E C-2)$.

The focus of eq. (2) is on $c_{1}$, the coefficient on $\triangle P B F S$. Rejection of the null hypothesis $\left(c_{1}<0\right)$ is consistent with value-relevant nonearnings data being disclosed at the time of the full financial statement disclosure [for the return interval $(S E C-1, S E C+1)$ ] or between the earnings announcement and the full financial statement disclosure [for return interval $(E A+2$, $S E C-2)]$.

\subsection{Results for the SEC interval}

The results of testing $\mathrm{H} 2_{0}$ using the three-day interval surrounding the filing of the full financial statements with the SEC are reported in table 5. The first row reports the results for the full sample of 4,375 firm-years. The coefficient on $\triangle P B F S, c_{1}$, is negative, but not significantly different from zero at the 10 percent level. Thus, it appears that in spite of the significant price response for the full year associated with revisions in the probability of bankruptcy due to nonearnings components reported in table 3 , this reaction does not coincide with disclosure of the full financial statements.

To determine whether this result may be attributable only to a relatively small number of firms with large changes in the probability of bankruptcy, we successively trimmed the sample on the basis of extreme observations of $\triangle P B F S$. The second, third, and fourth sets of results reported in table 5 are for reduced samples, with 2 percent, 10 percent, and 20 percent of the firm-years deleted. When the extreme 10 percent of the $\triangle P B F S$ observations are deleted, the coefficient on $\triangle P B F S$ is negative and significant at the 10 percent level. However, when either 2 or 20 percent of the sample is deleted, the coefficient is not significant at any conventional level. Finally, we estimated the regression on the full sample with available data, after ranking $\triangle P B F S$. For this ranked regression, the coefficient on $\triangle P B F S$ is negative and significant at the 16 percent level. At best, there is very weak evidence, attributable to relatively few firm-years, that there is a relation between security returns and changes in the probability of bankruptcy at the financial statement disclosure date.

To provide some sense of the power of our methodology we conducted a Brown and Warner $(1980,1985)$ type of simulation. To do this, we chose a three-day nondisclosure period $(S E C+9, S E C+11)$, the same length as the SEC interval, added (subtracted) 0.1 percent to (from) each firm-year's return 
Table 5

Regression tests of relation between excess returns and unexpected changes in the probability of bankruptcy, SEC interval, 4,375 firms, 1978-1984."

Model: $\quad U R_{i,(S E C-1, S E C+1)}=c_{0}+c_{1} \Delta P B F S_{i, t}+u_{i, t}$

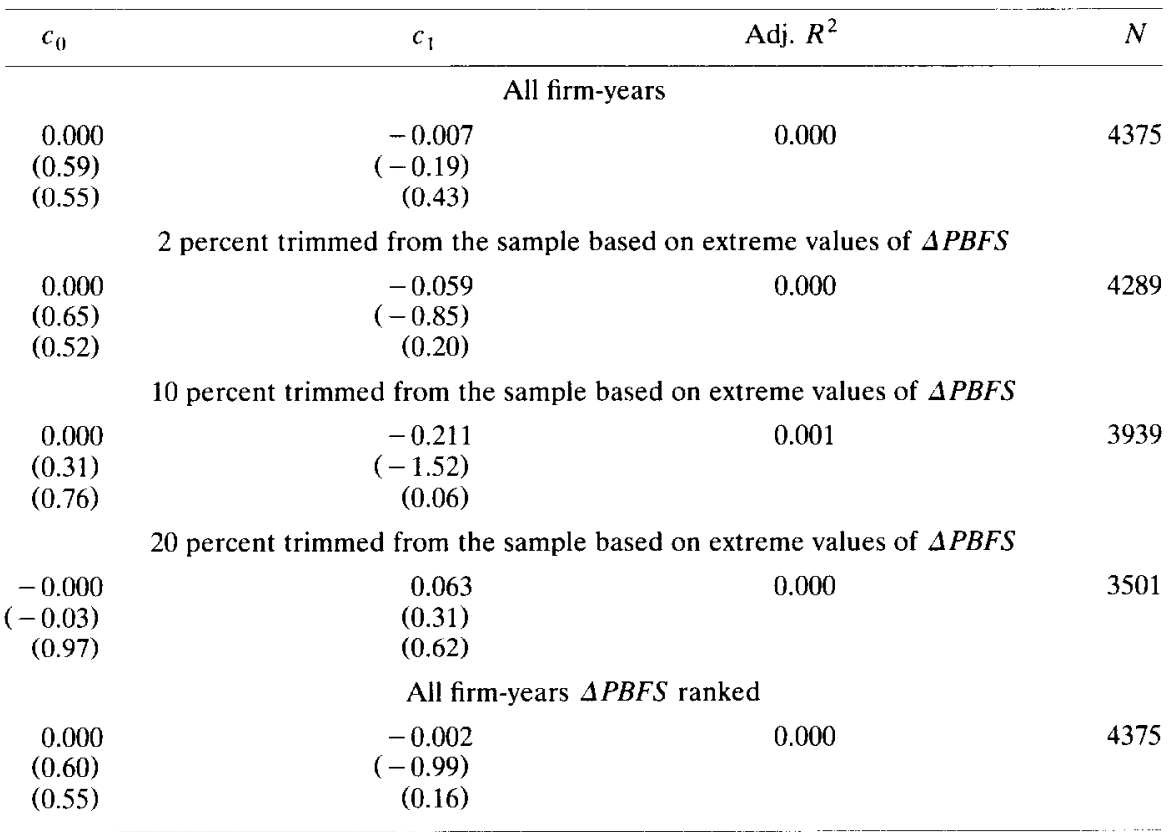

${ }^{2} U R_{i,(S E C-1, S E C+1)}=$ excess security returns cumulated from the day before until the day after the SEC disclosure date, which is the earlier of the annual report or 10-K filing date at the SEC. Unexpected returns are computed using a procedure that adjusts each firm's return for the mean return of firms of comparable size.

$\triangle P B F S_{i, \ell} \quad=$ unexpected change in the probability of bankruptcy at the financial statement release date, $P B\left(E_{i, t}, N E_{i, t}\right)-E_{E A}\left(P B_{i, t}\right)$, where $P B\left(E_{i, t}, N E_{i, t}\right)$ is based on current year actual earnings and nonearnings information, $E_{E A}\left(P B_{i, t}\right)=-0.0008+0.0445 P B\left(E_{i, t-4}, N E_{i, t-4}\right)$ $-0.2964 P B\left(E_{i, t-1}, N E_{i, t-1}\right)+1.2646 P B\left(E_{i, t}, N E_{i, t-1}\right)$, where the independent variables are: (i) the probability of bankruptcy at the beginning of the year based on last year's data, $P B\left(E_{i, t-4}, N E_{i, t-4}\right)$; (ii) the probability of bankruptcy based on the third-quarter financial statements, $P B\left(E_{i, t-1}, N E_{i, t-1}\right)$; (iii) the probability of bankruptcy based on the most current disclosed accounting information, $P B\left(E_{i, t}, N E_{i, t-1}\right)$. $N E_{i, t-1}$ is based on the assumption that investors know actual thirdquarter data for all of the nonearnings components of the bankruptcy index except funds provided by operations, which is estimated by adjusting estimated earnings by the mean nonfund accruals for the previous five years.

White (1980) adjusted $t$-statistics and the probability that the coefficient estimates are different from zero are reported in parentheses. Probability values are based on two-sided tests for the intercept and one-sided tests for the slope coefficient. 
if $\triangle P B F S$ for that firm-year is negative (positive), and re-estimated eq. (2). We continued to successively adjust each firm-year's return by 0.1 percent and re-estimate eq. (2) until the coefficient on $\triangle P B F S$ was significant at the 5 percent level. This occurred when firms' three-day returns were adjusted by 0.3 percent. Thus, our test appears capable of detecting a relatively small return associated with changes in the probability of bankruptcy. ${ }^{22}$

\subsection{Results for the interim interval}

To test the null hypothesis for the interim interval, we re-estimated eq. (2) with unexpected returns cumulated from two days after the annual earnings announcement until two days before the earlier of the 10-K filing or the annual report filing with the SEC. The median interval is 23 days, with a maximum (minimum) of 288 (3) days. As before, the focus is on $c_{1}$, the coefficient on $\triangle P B F S$, the revision in the probability of bankruptcy due to the release of nonearnings data.

The results for the interim interval are reported in table 6, which has the same format as table 5. For the full sample with available data, the coefficient on $\triangle P B F S, c_{1}$, is positive and insignificant. However, when extreme observations are trimmed from the sample, the cocfficient cstimate becomes significantly negative. When $10(20)$ percent of the sample is trimmed, the coefficient estimate is $-0.620(-1.372)$ with a $t$-statistic of $-2.00(-2.64)$. In addition, when $\triangle P B F S$ is ranked, the coefficient is also significantly negative $(t=-1.95)$. This provides evidence that is consistent with some leakage of relevant nonearnings information after the earnings announcement, but prior to the official disclosure of the full financial statements.

\section{Sensitivity analysis}

In this section, we conduct two types of sensitivity analysis on the main results in the paper, the estimation of eq. (2) for the SEC interval. The first type examines the sensitivity of the results to alternative specifications of the disclosure interval and to alternative subsets of the data for which our three-day SEC interval is more likely to coincide with the first disclosure of financial statement information. The second type examines whether disclosure of the full financial statements is associated with security returns for

\footnotetext{
${ }^{22}$ The coefficient on $\triangle P B F S$ from eq. (2) estimated over the interval $(S E C+9, S E C+11)$ was negative. To correct for this we employed the more conservative procedure of adjusting mean returns until the coefficient on $\triangle P B F S$ was slightly positive, and then initiated the simulation. Under these conditions, the coefficient on $\triangle P B F S$ became significantly negative at the 5 percent level when returns were adjusted by 0.5 percent. For comparison purposes, we computed the mean return associated with positive and negative announcements of unexpected earnings for our sample. Firms which disclosed positive (negative) unexpected earnings at the annual earnings announcement experienced a three-day return of 0.6 percent $(-0.7$ percent).
} 
Table 6

Regression tests of relation between excess returns and unexpected changes in the probability of bankruptcy, interim interval, 4,375 firms, $1978-1984 .^{\text {a }}$

Model: $\quad U R_{i,(E A+2, S E C-2)}=c_{0}+c_{1} \Delta P B F S_{i, t}+u_{i, t}$

\begin{tabular}{|c|c|c|c|}
\hline$c_{0}$ & $c_{1}$ & Adj. $R^{2}$ & $N$ \\
\hline \multicolumn{4}{|c|}{ All firm-years } \\
\hline $\begin{array}{c}0.001 \\
(0.90) \\
(0.37)\end{array}$ & $\begin{array}{c}0.043 \\
(0.55) \\
(0.71)\end{array}$ & 0.000 & 4375 \\
\hline
\end{tabular}

2 percent trimmed from the sample based on extreme values of $\triangle P B F S$

10 percent trimmed from the sample based on extreme values of $\triangle P B F S$

$$
\begin{array}{r}
-0.620 \\
(-2.00) \\
(0.02)
\end{array}
$$

0.001

20 percent trimmed from the sample based on extreme values of $\triangle P B F S$

$$
\begin{array}{r}
-1.372 \\
(-2.64) \\
(0.00)
\end{array}
$$

\section{All firm-years $\triangle P B F S$ ranked}

$$
\begin{array}{r}
-0.010 \\
(-1.95)
\end{array}
$$

$$
0.001
$$
${ }^{\mathrm{a}} U R_{i,(E A+2, S E C-2)}=$ excess security returns cumulated from two days after the earnings announcement until two days before the SEC disclosure date, which is the earlier of the annual report or 10-K filing date at the SEC. Unex- pected returns are computed using a procedure that adjusts each firm's return for the mean return of firms of comparable size.
$\triangle P B F S_{i, t} \quad=$ unexpected change in the probability of bankruptcy at the financial statement release date, $P B\left(E_{i, t}, N E_{i, t}\right)-E_{E A}\left(P B_{i, t}\right)$, where $P B\left(E_{i, t}, N E_{i, t}\right)$ is based on current year actual earnings and nonearnings information, $E_{E A}\left(P B_{i, t}\right)=-0.0008+0.0445 P B\left(E_{i, t-4}, N E_{i, t-4}\right)-$ $0.2964 P B\left(E_{i, t-1}, N E_{i, t-1}\right)+1.2646 P B\left(E_{i, t}, N E_{i, t-1}\right)$, where the inde- pendent variables are: (i) the probability of bankruptcy at the beginning of the year based on last year's data, $P B\left(E_{i, t-4}, N E_{i, t-4}\right)$; (ii) the probability of bankruptcy based on the third-quarter financial state- ments, $P B\left(E_{i, t-1}, N E_{i, t-1}\right)$; (iii) the probability of bankruptcy based on the most current disclosed accounting information, $P B\left(E_{i, l}, N E_{i, t-1}\right)$. $N E_{i, t-1}$ is based on the assumption that investors know actual third- quarter data for all of the nonearnings components of the bankruptcy index except funds provided by operations, which is estimated by adjust- ing estimated earnings by the mean nonfund accruals for the previous five years.

White (1980) adjusted $t$-statistics and the probability that the coefficient estimates are different from zero are reported in parentheses. Probability values are based on two-sided tests for the intercept and one-sided tests for the slope coefficient. 
firm-years for which nonearnings data were more significantly related to returns over the entire fiscal year, due to either a large unexpected change in the probability of bankruptcy or negative unexpected earnings.

\subsection{Specification of the disclosure interval}

For the tests reported in section 4 , we cumulate returns over the three days centered on the earlier of the annual report or $10-\mathrm{K}$ filing with the SEC. By centering the interval on the SEC date we assume that the information is available to investors at approximately the same time it is received by the SEC. When the annual report is received by the SEC before the 10-K filing, this assumption appears reasonable. Based on evidence in Wilson (1987), firms generally mail their annual reports to shareholders within two days of when the reports are mailed to the SEC. However, when the $10-\mathrm{K}$ filing is received by the SEC before the annual report, the appropriateness of the receipt date is not as clear. Use of the receipt date as the center of the event interval is certainly appropriate if firms release information directly to investors through alternative media at the same time they file the $10-\mathrm{K}$ with the SEC. ${ }^{23}$ On the other hand, if the SEC is the first source of the information for investors, the process at the SEC creates difficulty in identifying the correct date. When the filing is received, one copy goes to the public reference room the same day and another copy is sent to be microfiched. It is difficult to access the hardcopy in the public reference room because the filings are not organized or catalogued immediately. This potential for delay in physical availability is exacerbated for much of the sample by the large number of $12 / 3110-\mathrm{K}$ filings received over a relatively short interval. ${ }^{24}$

It is possible that the lack of results for the SEC interval could be due to an inaccurate specification of the event date. To address this uncertainty, we conducted several supplementary analyses. First, we repeated our main analysis using five- and nine-day return intervals centered on the SEC disclosure date. If the event date is measured with substantial uncertainty such that expanding the return interval improves the signal to noise ratio, our results should be stronger for these intervals. However, the results are weaker when the return interval is lengthened, regardless of how the sample is trimmed or whether the regression is estimated on the basis of ranks.

Second, we performed a separate analysis for the subset of firms whose annual report is received by the SEC before, or on the same date as, the $10-\mathrm{K}$

\footnotetext{
${ }^{23}$ From our 212 usable survey responses, 134 ( 63 percent) indicated that they do not send their annual report, $10-\mathrm{K}$, or fourth-quarter report (if they prepare one) to either shareholders or analysts/brokers more than three days before mailing their 10-K to the SEC.

${ }^{24}$ Our understanding of the process is based on a telephone conversation with staff of the SEC Public Affairs Office.
} 
is received. A three-day interval centered around this date should include the date that the financial statements become available to investors for this subset of firms. The results for this analysis are similar to those reported for the whole sample. For this subsample, the coefficient on $\triangle P B F S$ is not significantly negative at the 10 percent level regardless of how the sample is trimmed or whether the regression is estimated on the basis of ranks.

Third, to identify firms for which the SEC date is likely to be a reasonable estimate of the first day the financial statements are publicly available, we sent a survey to a randomly selected subset of half of the firms in our sample, requesting information about each firm's financial statement dissemination policy. We sent out 646 surveys and received 212 usable responses. Of these, 134 firms, representing 482 firm-years in our sample, indicated that they did not mail their annual report or form $10-\mathrm{K}$ (or fourth-quarter report if they prepare one) to either shareholders or analysts more than three days before they mail it to the SEC. We re-estimated eq. (2) for this subsample and obtained some weak evidence consistent with rejection of the null hypothesis. For this subsample, when 10 percent of the sample is trimmed, the coefficient on $\triangle P B F S$ is significantly negative at the 10 percent level. In addition, when the regression is estimated on the basis of ranks, the coefficient on $\triangle P B F S$ is significantly negative at the 5 percent level.

\subsection{Selected subsets of the sample}

The results from table 3 indicated that nonearnings information had the most explanatory power when the unexpected change in the probability of bankruptcy was large. To examine this more closely, we re-estimated eq. (2) for the extreme 20 percent of the $\triangle P B$ distribution. For this subsample, the coefficient estimate on $\triangle P B F S$ was virtually zero $(t=0.19)$. Thus, there is no evidence for this subsample that the security price reaction documented in table 3 occurred at the disclosure of the full financial statements.

The results from table 4 in section 3 indicated that nonearnings information had the most explanatory power when unexpected earnings was negative. To examine this more closely, we re-estimated eq. (2) for firms with negative unexpected earnings. For this subsample, the coefficient on $\triangle P B F S$ is not significantly negative at the 10 percent level regardless of how the sample is trimmed or whether the regression is estimated on the basis of ranks.

\section{Conclusions}

The objective of this study is to examine the communication value of accounting disclosures of information other than earnings. To examine this issue, we conducted tests for an association between security returns and revisions in investor estimates of the probability of bankruptcy that are due 
to nonearnings information. We estimated the association of unexpected changes in the probability of bankruptcy with security returns over three return intervals, one to establish the potential value of nonearnings information and the other two to focus on disclosure of the full financial statements.

The first interval is the period from the beginning of the fiscal year until the disclosure of the full financial statements. The results for this period support the existence of an association between changes in the probability of bankruptcy due to nonearnings information and security returns, after controlling for the relation between unexpected earnings and returns and the effect of earnings changes on the probability of bankruptcy. The results are particularly strong for those firm-years that had the largest change in the probability of bankruptcy. This indicates that nonearnings information about the probability of bankruptcy is useful to investors and that the disclosure of such information at the SEC filing date has potential communication value.

For the period surrounding the SEC disclosure date, there is, at best, very weak evidence that investors receive information that is useful in adjusting their estimates of the probability of bankruptcy. In addition, there is some evidence that during the period between the earnings announcement and the SEC disclosure date useful information is communicated. However, the disclosure impact during the financial statement release period docs not appear to be either strong or systematic. Disclosure impact of annual financial statements may be more likely to occur in specific time periods [Wilson (1987)] or industries [Wahlen (1991)]. Wahlen concludes that he was able to detect some communication value at the financial statement release date because of the specific industry context he was examining (loan loss information in the banking industry). In summary, our analysis indicates that almost all of the information contained in annual financial statement disclosures that are required by the SFC is impounded in security prices before the financial statements are filed with the SEC.

\section{References}

Ball, Ray and Philip Brown, 1968, An empirical evaluation of accounting income numbers, Journal of Accounting Research 6, 159-178.

Beaver, William H., 1968, The information content of annual earnings announcements, Journal of Accounting Research 6, 67-92.

Bernard, Victor L. and Thomas L. Stober, 1989, The nature and amount of information in cash flows and accruals, The Accounting Review LXIV, 624-652.

Bernard, Victor L. and Jacob K. Thomas, 1989, Post-earnings-announcement drift: Additional evidence, Journal of Accounting Research 27, 1-36.

Brown, S. and J. Warner, 1980, Measuring security price performance, Journal of Financial Economics 12, 205-258.

Brown, S. and J. Warner, 1985, Using daily stock returns: The case of security price performance, Journal of Financial Economics 17, 3-32.

Burgstahler, David, James Jiambolvo, and Eric Noreen, 1989, Changes in the probability of bankruptcy and equity value, Journal of Accounting and Economics 11, 207-224. 
Foster, George, 1986, Financial statement analysis (Prentice-Hall, Englewood Cliffs, NJ).

Morse, Dale, 1981, Price and trading volume reaction surrounding earnings announcements: A closer examination, Journal of Accounting Research 19, 374-383.

Ohlson, James, 1980, Financial ratios and the probabilistic prediction of bankruptcy, Journal of Accounting Research 18, 109-131.

Ou, Jane A., 1990, The information content of non-earnings accounting numbers, Journal of Accounting Research 28, 144-163.

Ou, Jane A. and Stephen H. Penman, 1989, Financial statement analysis and the prediction of stock returns, Journal of Accounting and Economics 11, 295-329.

Patell, James M. and Mark A. Wolfson, 1984, The intraday speed of adjustment of stock prices to earnings and dividend announcements, Journal of Financial Economics 13, 223-252.

Thompson, Robert B., II, Chris Olsen, and J. Richard Dietrich, 1987, Attributes of news about firms: An analysis of firm-specific news reported in the Wall Street Journal Index, Journal of Accounting Research 25, 245-274.

Wahlen, James M., 1991, The nature of information in commercial bank loan loss disclosures, Working paper (University of Michigan, Ann Arbor, MI).

White, Halbert, 1980, A heteroskedasticity-consistent covariance matrix estimator and a direct test for heteroskedasticity, Econometrica 40, 817-838.

Wilson, G. Peter, 1987, The incremental information content of the accrual and funds components of earnings after controlling for earnings, The Accounting Review LXII, 293-322.

Zmijewski, Mark, 1983, An indirect test of the economic significance of bankruptcy costs, Working paper (State University of New York, Buffalo, NY). 